ORIGINAL ARTICLE

\title{
Density management in clonal Tectona grandis Linn. f. plantations
}

\author{
Manejo da densidade em plantações clonais de Tectona grandis Linn. f.
}

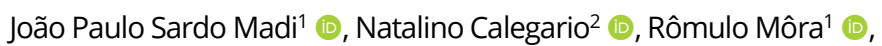

Mariana Peres de Lima Chaves e Carvalho' 1 (i), Samuel de Padua Chaves e Carvalho' (1)

${ }^{1}$ Universidade Federal de Mato Grosso - UFMT, Cuiabá, MT, Brasil

2Universidade Federal de Lavras - UFLA, Lavras, MG, Brasil

How to cite: Madi, J. P. S., Calegario, N., Môra, R., Carvalho, M. P. L. C., \& Carvalho, S. P. C. (2020). Density management in clonal Tectona grandis Linn. f. plantations. Scientia Forestalis, 48(125), e3296.

https://doi.org/10.18671/scifor.v48n125.25

\begin{abstract}
This study aimed to develop a Density Management Diagram (DMD) for clonal commercial stands of Tectona grandis Linn. $\mathrm{f}$ of up to 8 years, in the Center-South region of the state of Mato Grosso, Brazil. The DMD related the variables "number of plants per hectare" (N), "quadratic mean diameter" (dg), "mean dominant height" (dh), "volume" (V), and "stand density index" (SDI) using the Reineke model, with a fixed exponent of -1.605. The ranges of optimal management were based on Kumar et al. (1995). The system of equations proposed by Dean and Baldwin (1993) was used to represent the isolines of dominant height and volume. The adjusted system of equations presented satisfactory statistics and the DMD enabled the development of different scenario simulations for the management of this species, helping managers in the decision-making. The results of this study showed that thinnings were being performed too early in the studied areas, therefore revealing the need to change the frequency of this silvicultural practice.
\end{abstract}

Keywords: Density management diagram; Stand density; Reineke index, Thinning.

\section{Resumo}

O objetivo deste trabalho foi desenvolver um Diagrama de Manejo da Densidade (DMD) para plantios comerciais clonais de Tectona grandis Linn. f. O estudo foi realizado em plantios comerciais clonais na região centro - sul do estado de Mato Grosso, Brasil com até 8 anos de idade. O DMD relacionou as variáveis número de plantas por hectare $(\mathrm{N})$, diâmetro médio quadrático $(\mathrm{dg})$, altura média dominante (hd), volume do povoamento (V) e o índice de densidade de povoamento (IDP) a partir do modelo de Reineke, com expoente fixo de -1,605. As faixas ideais de manejo foram baseadas no trabalho de Kumar et al. (1995). Para representação das isolinhas da altura dominante e do volume foi utilizado o sistema de equações proposto por Dean e Baldwin (1993). O sistema de equações ajustado apresentou estatísticas satisfatórias e o DMD permitiu a simulação de cenários para o manejo desta espécie, auxiliando na tomada de decisões. Os resultados da pesquisa permitiram inferir que os desbastes estão ocorrendo precocemente nas áreas em estudo, demonstrando, portanto, a necessidade de revisão da periodicidade desta prática silvicultural.

Palavras-chave: Diagrama de manejo da densidade; Estoque florestal; Índice de Reineke; Desbaste.

\section{INTRODUCTION}

Density management might be defined as the manipulation and control of the stand stock to reach the specific objectives of management (Long, 1985). This manipulation, according to Dean \& Baldwin (1993), might be carried out through thinnings, therefore

Financial support: Coordenação de Aperfeiçoamento de Pessoal de Nível Superior - CAPES.

Conflict of interest: Nothing to declare.

Corresponding author: joaosardomadi@gmail.com

Received: 26 February 2019.

Accepted: 24 June 2019.

Editor: Francides Gomes da Silva Júnior.

(i) This is an Open Access article distributed under the terms of the Creative Commons Attribution License, which permits unrestricted use, distribution, and reproduction in any medium, provided the original work is properly cited. 
preventing mortality by competition, prioritizing the production, and timber quality at the individual level. The same authors highlighted that if the thinning is done at an inadequate time, it might result in the reduction of forest productivity. Thus, if this procedure is performed too early it might result in stand stock losses and if it is carried out too late, the trees of the population might respond slowly to this procedure.

Thinning is regarded by Castedo-Dorado et al. (2009) as a complex activity in forest management due to the great number of possible treatments that might be performed. Such practice is associated to long-term crop rotation of plants that have a high-aggregated value. Thus, it is important to adopt procedures like the density management diagram that help managers in deciding the moment of intervening in the population.

The Density Management Diagram (DMD) is one of the most efficient tools to guide thinnings since it allows the graphic display of the forest stand dynamics. The DMDs are population models that, when graphically represented, show the relation between productivity, density, and mortality at many different stages of the population development (Newton \& Weetman, 1994).

In practice, the DMDs allow the simulation of different management regime scenarios and the development of thinning schedules for a wide range of sites and management objectives (Castedo-Dorado et al., 2009).

Therefore, the DMDs become a valuable tool when used especially for long-term crop rotations, such as those of Tectona grandis Linn f. (teak). In Brazil, the teak forest formations are managed to yield large dimension products processed in sawmills, mostly with a 20-year rotation (Arias, 2013), therefore warranting the use of DMDs.

In view of the foregoing, this work aimed to develop a density managing diagram for clonal populations of Tectona grandis, in the Central-South region of the state of Mato Grosso, Brazil.

\section{MATERIAL AND METHODS}

\section{Study area}

The data were collected from commercial stands of Tectona grandis, in a total area of 3,078.34 ha, located in the Central-South region of the state of Mato Grosso, Brazil (Figure 1).

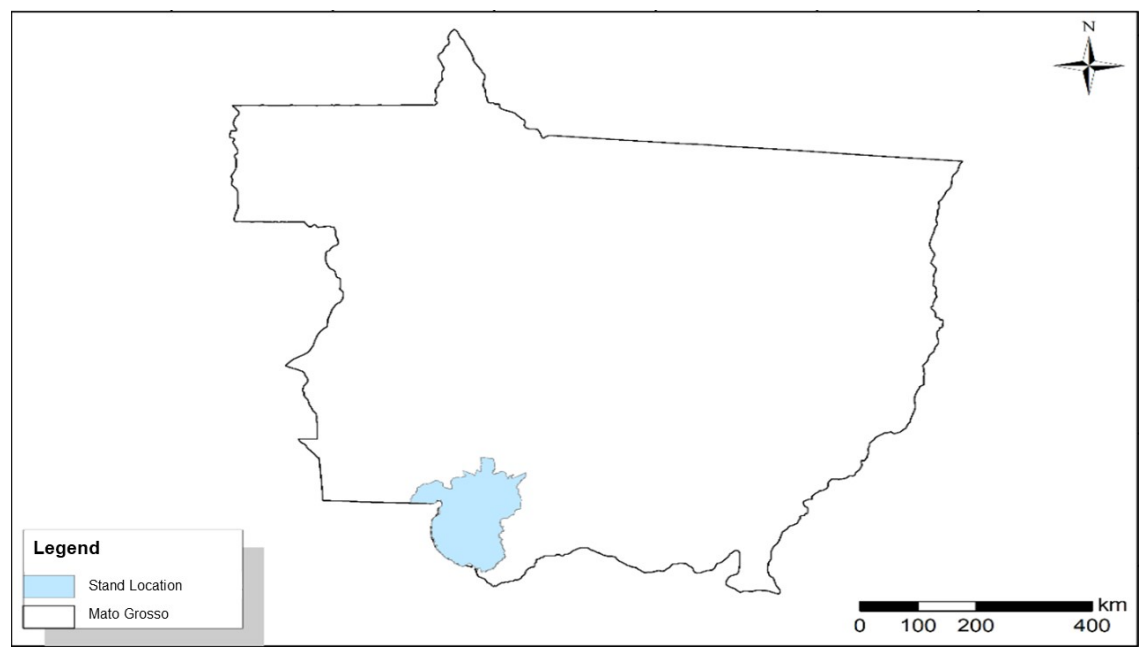

Figure 1 -Study area: Tectona grandis plantation.

The region presents altitudes varying between $100 \mathrm{~m}$ and $200 \mathrm{~m}$; mean, maximum, and minimum temperatures of $25.4^{\circ} \mathrm{C}, 32.9^{\circ} \mathrm{C}$, and $20.9^{\circ} \mathrm{C}$, respectively; total annual rainfall between $1300 \mathrm{~mm}-1400 \mathrm{~mm}$ (Mato Grosso, 2011). 
According to Pandey \& Brown (2000) the optimal conditions for teak plantation are a rainfall varying from $1250 \mathrm{~mm}$ to $3750 \mathrm{~mm}$, with minimal temperatures ranging from $13^{\circ} \mathrm{C}$ to $17^{\circ} \mathrm{C}$ and maximum temperatures from $39^{\circ}$ to $43^{\circ} \mathrm{C}$; deep permeable soil, with reasonable ability of water retention and medium to fertile soils.

According to the classification of Köppen, the weather of the region is classified as Aw, with a rainy summer and a dry period in winter (Alvares et al., 2013).

\section{Data base}

The data of this investigation were collected from clonal teak stands ranging from 1 to 8 years old, with the oldest stand being from 2004. The usable area per plant varied from 9 to $100 \mathrm{~m}^{2}$, with spacings of $10 \mathrm{~m} \times 10 \mathrm{~m}, 3 \mathrm{~m} \times 3 \mathrm{~m}, 4 \mathrm{~m} \times 2.5 \mathrm{~m}, 4 \mathrm{~m} \times 3 \mathrm{~m}$, and $4 \times 4 \mathrm{~m}$.

The data were collected in circular sample units, amounting to 587 samples, with the area ranging from $359 \mathrm{~m}^{2}$ to $616 \mathrm{~m}^{2}$. The chest height diameter (CHD), and the total heights were measured from the trees that comprised the sample units. A total of 827 trees were scaled by destructive and non-destructive methods, the latter using an optic dendrometer (Criterion $\mathrm{RD}^{\circledR} 1000$ ), in order to form the baseline volume.

The estimates from each tree from the sample units were obtained by the Schumacher \& Hall (1933) model (Equation 1), based on the data from the scaled trees:

$$
\mathrm{v}_{\mathrm{i}}=\beta_{0} \mathrm{DAP}_{\mathrm{i}}^{\beta_{1}} \mathrm{hti}_{\mathrm{i}}^{\beta_{2}}+\varepsilon_{\mathrm{i}}
$$

in which: $v_{i}=$ volume of the $\mathrm{i}$-th tree $\left(\mathrm{m}^{3}\right) ; \operatorname{DAP}_{\mathrm{i}}=$ chest height diameter of the i-th tree $(\mathrm{cm})$; $\mathrm{ht}_{\mathrm{i}}=$ total height of the $\mathrm{i}$-th tree $(\mathrm{m}) ; \beta_{\mathrm{i}}=$ estimated coefficients; $\varepsilon_{\mathrm{i}}=$ random error.

Later, the following information was generated about the crop: density (number of plants per hectare) $(N)$, quadratic mean diameter $\left(\mathrm{d}_{\mathrm{g}}\right)$, dominant height (using the Assmann method (1970)) $\left(h_{\text {dom }}\right)$, total volume of the sample unit $(V)$, and the Reineke density index (RDI), with a fixed exponent of -1.605 (Reineke, 1933), since it was a population thinned forest.

\section{Statistical analysis}

The system of models proposed by Dean \& Baldwin (1993) (Equation 2 and Equation 3) were proposed for the construction of the density management diagram.

$$
\begin{aligned}
& \mathrm{dg}_{\mathrm{i}}=\beta_{0} \mathrm{~N}_{\mathrm{i}}{ }^{\beta_{1}} \mathrm{~V}_{\mathrm{i}}^{\beta_{2}}+\varepsilon_{\mathrm{i}} \\
& \mathrm{V}_{\mathrm{i}}=\beta_{3} \mathrm{dg}_{\mathrm{i}}{ }^{\beta_{4}} \text { hdom }_{\mathrm{i}}{ }^{{ }{ }_{5}} \mathrm{~N}_{\mathrm{i}}+\varepsilon_{\mathrm{i}}
\end{aligned}
$$

in which: $\mathrm{dg}=$ quadratic mean diameter of the i-th sample unit $(\mathrm{cm}) ; \mathrm{v}=$ volume of the i-th sample unit $\left(\mathrm{m}^{3} \cdot \mathrm{ha}^{-1}\right) ; \mathrm{N}=$ number of plants per ha of the i-th sample unit ; hdom $=$ dominant height; $\beta_{\mathrm{i}}=$ estimated coefficients; $\varepsilon_{\mathrm{i}}=$ random error.

After the models were adjusted, their biases were graphically shown, where " $x$ " linearly represents dg and " $y$ " the stock density in logarithmic scale. The RDI, V, and hdom isolines were added to the graphic. These variables were shown in the graph based on the adjusted models rearranged due to $\mathrm{N}$, with the isolines of volume (Equation 4) and dominant height (Equation 5). The RDI isolines were represented by the Reineke model, using the a fixed exponent of -1.605 . 


$$
\begin{aligned}
& \mathrm{N}=\left(\frac{\mathrm{dg}}{\beta_{0} \mathrm{~V}^{\beta_{2}}}\right)^{\frac{1}{\beta_{1}}} \\
& \mathrm{~N}=\left(\frac{\mathrm{dg}^{\left(1-\beta_{2} \beta_{4}\right)}}{\beta_{0} \beta_{3}{ }^{\beta_{2}} \mathrm{hdom}^{\left(\beta_{5} \beta_{2}\right)}}\right)^{\frac{1}{\left(\beta_{2}+\beta_{1}\right)}} \\
& \mathrm{RDI}=\mathrm{N}\left(\frac{\mathrm{d}_{\mathrm{g}}}{25}\right)^{-1.605}
\end{aligned}
$$

in which: $\mathrm{dg}=$ quadratic mean diameter; $\mathrm{v}=$ volume $\left(\mathrm{m}^{3} \cdot \mathrm{ha}^{-1}\right) ; \mathrm{N}=$ number of plants per ha; RDI $=$ Reineke density index; $\beta_{\mathrm{i}}=$ estimated coefficient.

The calculation of the RDIs was based on the works of Minoche et al. (2017) and Kumar et al. (1995) using the average value of the above mentioned studies, performed with teak, resulting in an RDI of 1100 regarding $100 \%$.

The lines of the Reineke density index were represented in the $100 \%, 60 \%, 50 \%, 35 \%$, and $20 \%$ values, referring to the $1100,660,550,385$, and 220 RDI values, respectively. These percent values were based in the works of Minoche et al. (2017) and Kumar et al. (1995)

Two different scenarios were created for managing the studied stands. The first used optimal ranges of management that varied between $35 \%$ and $60 \%$, corresponding to SDIs of 385 e 660, respectively, with the aim of obtaining smaller logs, with dg of $25 \mathrm{~cm}$. The second scenario had the purpose of producing larger timber suited for sawmills, with a dg of $35.7 \mathrm{~cm}$, the SDIs of 385 and 220, resulting in 35\% and 20\% of the highest SDI.

Two optimal management ranges were based in the study of Kumar et al. (1995), since the first range of management targets the maximal potential use of the site without the occurrence of auto-thinning, while the second range of management favors the individual growth of the trees, desired in the intensive management.

The initial mortality was set at $10 \%$, according to the data of the company.

\section{Assessing the accuracy of the models}

First, the t-test was performed to evaluate the significance of the coefficients at the $95 \%$ confidence level.

The accuracy of the adjusted models was assessed by the graphical analysis of the residues in a percent scale (Equation 7), the percent coefficient of correlation (Equation 8), and by the standard error of the estimate (Equation 9 and Equation 10)

$$
\begin{aligned}
& \text { Residue }(\%)=\frac{y_{i}-\hat{y}_{i}}{y_{i}} 100 \\
& R^{2}(\%)=\frac{\left[\sum_{i=1}^{n} y_{i} \hat{y}_{i}-\frac{\left(\sum_{i=1}^{n} \hat{y}_{i}\right)\left(\sum_{i=1}^{n} y_{i}\right)}{n}\right]^{2}}{\left[\sum_{i=1}^{n} y_{i}^{2}-\frac{\sum_{i=1}^{n} y_{i}^{2}}{n}\right]\left[\sum_{i=1}^{n} \hat{y}_{i}^{2}-\frac{\left(\sum_{i=1}^{n} \hat{y}_{i}\right)^{2}}{n}\right]^{100}} \\
& \text { Syx }=\sqrt{\frac{\sum_{i=1}^{n}\left(y_{i}-\hat{y}_{i}\right)^{2}}{n-p-1}}
\end{aligned}
$$




$$
\operatorname{Syx}(\%)=\frac{\operatorname{Syx}}{\bar{y}} 100
$$

in which: $\mathrm{y}_{\mathrm{i}}=$ observed value; $\widehat{\mathrm{y}_{\mathrm{i}}}=$ estimated value; $\overline{\mathrm{y}}_{\mathrm{i}}=$ observed mean; $\mathrm{n}=$ number of observations; $\mathrm{p}=$ coefficient number of the model; Syx = standard error of the estimate.

\section{Data processing}

Data processing, model adjustment, statistics calculation, and the plotting of graphs, as well as the DMD, were made using the software R (R Core Team, 2017a), using the dplyr (Wickham et al., 2018), bbmle (R Core Team, 2017b), and lattice (Sarkar, 2008) statistical packages.

\section{RESULTS AND DISCUSSION}

The Dean \& Baldwin (1993) system, proposed for the calculation of the isolines, presented good adjustments to the data of this study. The statistics were accurate, with high coefficient of determination and low mean errors (Table1).

Table 1 - Statistics of the models used in the construction of the density management diagram.

\begin{tabular}{cccccc}
\hline Model & Coefficient & Standard Error & $\mathbf{R}^{\mathbf{2}}$ (\%) & Syx & Syx (\%) \\
\hline & $\beta_{0}=40.7292^{*}$ & 0.3153 & & 0.39 & \\
$\mathrm{dg}=\beta_{0} \mathrm{~N}^{\beta_{1}} \mathrm{~V}^{\beta_{2}}$ & $\beta_{1}=-0.4079^{*}$ & 0.0012 & 99.37 & $(\mathrm{~cm})$ & 3.03 \\
& $\beta_{2}=0.3882^{*}$ & 0.0011 & & & \\
& $\beta_{3}=1.108 .10^{-4 *}$ & 0.0000 & & 0.4748 & 1.84 \\
$\mathrm{~V}=\beta_{3} \mathrm{dg}^{\beta_{4}} \mathrm{hdom}^{\beta_{5} \mathrm{~N}}$ & $\beta_{4}=2.3830^{*}$ & 0.006 & 99.81 & $\left(\mathrm{~m}^{3} \cdot \mathrm{ha}^{-1}\right)$ & \\
& $\beta_{5}=0.1467^{*}$ & 0.0064 & &
\end{tabular}

in which: $\mathrm{dg}=$ quadratic mean diameter $(\mathrm{cm}) ; \mathrm{N}=$ number of plants.ha-1 $; \mathrm{V}=$ stand volume $\left(\mathrm{m}^{3} \cdot \mathrm{ha}^{-1}\right) ;$ hdom . = dominant height $(\mathrm{m}) ; \beta_{\mathrm{i}}=$ coefficients to be estimated; $\mathrm{R}^{2}(\%)=$ square of the correlation coefficient; Syx = standard error of the estimate; Syx $\%=$ percent standard error (\%). Obs = * significant coefficients at the $95 \%$ probability level.

The coefficients of the models were highly significant (Table 1) at a pbability level of $95 \%$, implying that the coefficients associated to the independent variable explained the variation of the dependent variable. The $\mathrm{R}^{2}(\%)$ and Syx (\%) values indicate the quality of the adjustment, since the obtained $\mathrm{R}^{2}(\%)$ was higher than $90 \%$ and the Syx (\%) lower than $3 \%$. Retslaff et al. (2016), working with Pinus taeda, recorded standard errors of $4.9 \%$ and $11.04 \%$ for the adjustments of the quadratic mean diameter and volume of the population, respectively. The same parameter was lower when compared to the work of Dean \& Baldwin (1993) with Pinus taeda, with approximately $1.4 \mathrm{~cm}$ for the diameter and $36.664 \mathrm{~m}^{3} . \mathrm{ha}^{-1}$ for the volume of the population.

The residues of the graphic of the equation of the quadratic mean diameter show (Figure 2) a balanced distribution, that is, one with low bias in the estimates, with the lowest percent value was -9.308 and the highest was 9.5392. The volume model showed bias for the estimated volume, when there was an increase in the standing stock. Such bias overestimated the volume, which ranged from -11.15 to $4.48 \%$. Despite presenting some bias at extreme values, the volume model is recommended since it presented satisfactory statistics and low percent errors. 

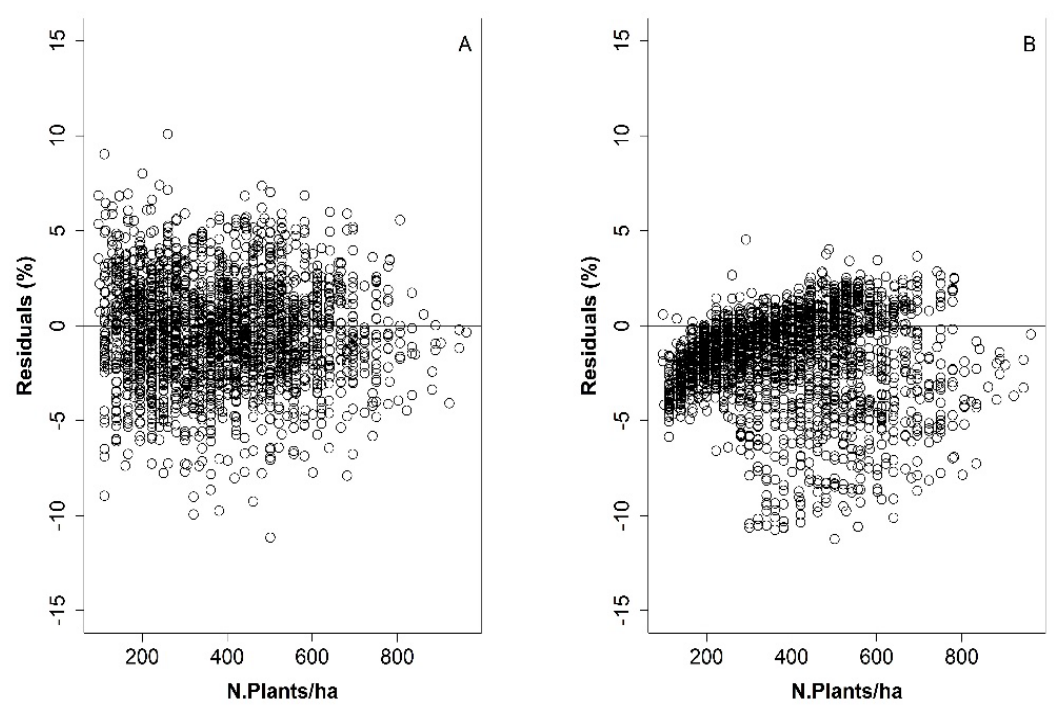

Figure 2 - Residuals of fitted models used for estimate stand density (N.Plants/ha). A= model 2, $\mathrm{B}=$ model 3 .

The management diagram was developed considering $4 \mathrm{~m}$ intervals for the generation of dominant height isolines, varying from 8 to $36 \mathrm{~m}$. For volume, this variation was from $25 \mathrm{~m}^{3}$.ha-1 to $500 \mathrm{~m}^{3}$.ha-1. The plot area is dimensioned by the standing stock in logarithmic scale (y), varying from 50 to 1600 individuals per hectare, and " $x$ " is about the quadratic mean diameter (dg). This corroborated the works of Minoche et al. (2017) and Valbuena et al. (2008), who reported that volume, density index, and Reineke dominant height might be obtained through the number of plants in the population and the quadratic mean diameter.

Figure 3 represents the findings of the investigation, namely, the DMD and all its components, that is, the isolines related to each variable (volume of the population; dominant height; and Reineke density index).

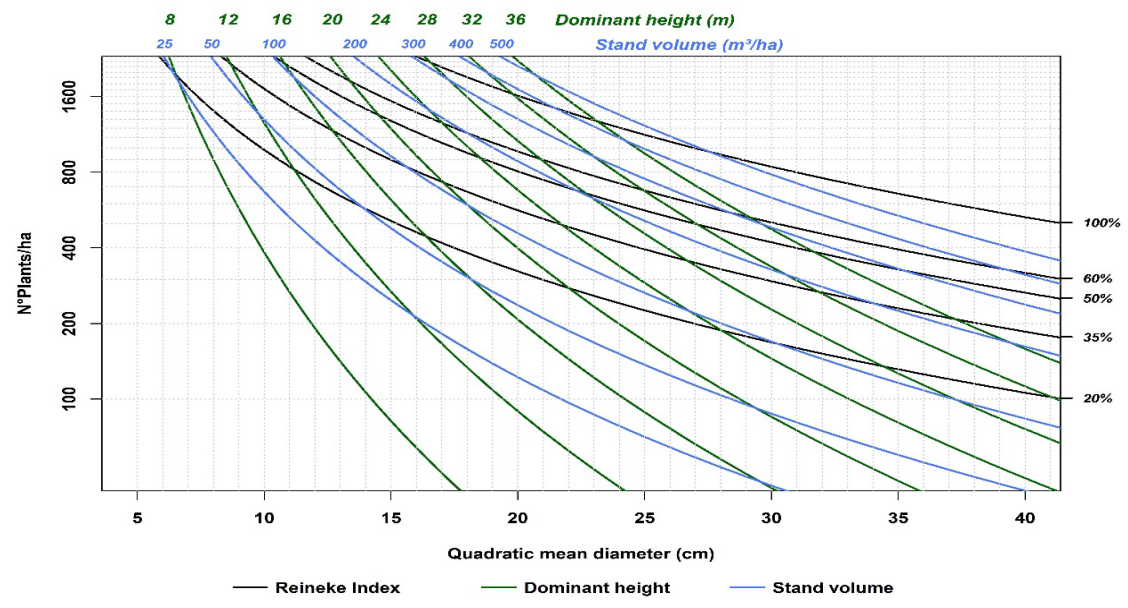

Figure 3 - Density management diagram for Tectona grandis.

According to Kumar et al. (1995), the optimal management range for volumetric production at the population level is between $35 \%$ and $60 \%$, although it results in smaller timber, with the population presenting $25 \mathrm{~cm}$ of $\mathrm{dg}$. When the goal is to obtain larger logs, with trees with $35.7 \mathrm{dg}$, favoring the individual development of the trees, the optimal range is between $35 \%$ and $20 \%$. 
Due to this management variation, two situations were simulated. Figure 4 represents the first scenario and Figure 5 the second one.

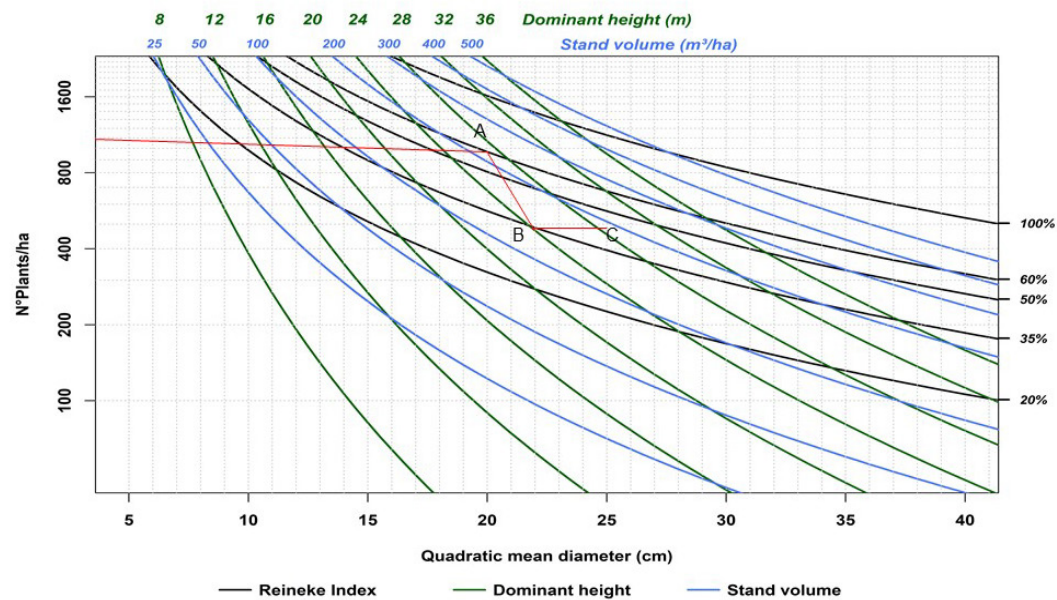

Figure 4 - Thinning simulation in a $3 \times 3$ m design.

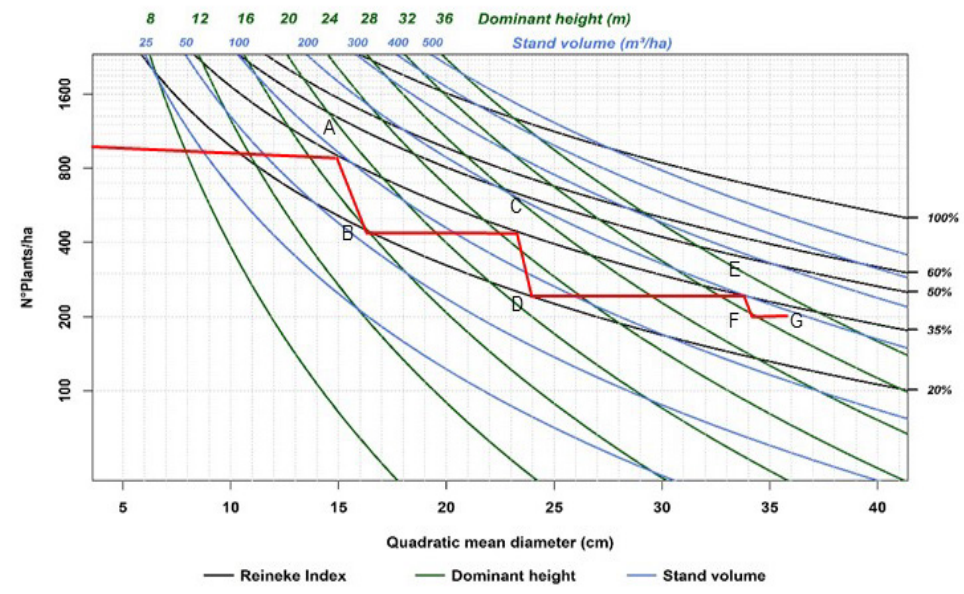

Figure 5 - Thinning simulation in a $4 \times 2.5$ m design.

The horizontal line shows the natural growth of the population, which reveals an increase of dg maintaining the standing stock. The inclined lines represent the thinning and their slope the degree of selectivity of such activity, that is, the higher the slope the higher selectivity of the thinning.

In both scenarios there was a reduction of the standing stock caused by the thinning, although the dg has increased and the volume tended to recover as the dg increased, guiding them between the respective management zones.

The time of the thinning and the recovering of the population production depend also on the quality of the site, guided by the isolines of dominant height, in which late thinnings are recommended in poor quality sites.

In the first scenario (Figure 4) the final cut occurred before the second scenario (Figure 5), although the individual volume of the trees is smaller than those from scenery two (Table 2). This scenario is used for the demonstration of a management system, in which the objective is produce logs with a dg of up to $25 \mathrm{~cm}$, destined to posts, poles, and fences, among other uses with a low-aggregated value. However, in this scenario, the volume at the population level is higher and the crop rotation is lower when compared to the management systems that targets the production of logs for sawmills with more than $35.7 \mathrm{~cm}$. 
Table 2 - Density management for two situations of clonal stands of Tectona grandis at the state of Mato Grosso.

\begin{tabular}{|c|c|c|c|c|c|c|c|c|c|}
\hline \multicolumn{10}{|c|}{ Situation 1} \\
\hline \multirow[t]{2}{*}{ Phase } & \multicolumn{2}{|c|}{$\begin{array}{c}d_{g} \\
(\mathrm{~cm})\end{array}$} & \multicolumn{2}{|c|}{$\begin{array}{c}\mathrm{N} \\
\left(\text { trees. } \mathrm{ha}^{-1}\right)\end{array}$} & \multicolumn{2}{|c|}{$\begin{array}{c}V \\
\left(\mathrm{~m}^{3} \cdot h \mathrm{a}^{-1}\right)\end{array}$} & \multicolumn{2}{|c|}{$\begin{array}{c}\text { Variation } \\
\left(\mathrm{m}^{3} \cdot \mathrm{ha}^{-1}\right)\end{array}$} & \multirow{2}{*}{$\begin{array}{l}\text { Source of } \\
\text { Change }\end{array}$} \\
\hline & Before & After & Before & After & Before & After & Thinning & Growth & \\
\hline $0-A$ & 4 & 20 & 1100 & 990 & 3.9775 & 224.8211 & - & 220.8435 & NG \\
\hline$A-B$ & 20 & 21.8 & 990 & 495 & 224.8211 & 135.5047 & 89.3164 & - & $\mathrm{T}$ \\
\hline$B-C$ & 21.8 & 25 & 495 & 0 & 135.5047 & 192.8245 & 192.8245 & 57.3198 & FC \\
\hline \multicolumn{10}{|c|}{ Situation 2} \\
\hline \multirow[t]{2}{*}{ Phase } & \multicolumn{2}{|c|}{$\begin{array}{c}d_{g} \\
(\mathrm{~cm})\end{array}$} & \multicolumn{2}{|c|}{$\begin{array}{c}\mathbf{N} \\
\left.\text { (trees.ha-1) }^{-1}\right)\end{array}$} & \multicolumn{2}{|c|}{$\begin{array}{c}V \\
\left(m^{3} \cdot h a^{-1}\right)\end{array}$} & \multicolumn{2}{|c|}{$\begin{array}{l}\text { Variation } \\
\left(\mathrm{m}^{3} \cdot \mathrm{ha}^{-1}\right)\end{array}$} & \\
\hline & Before & After & Before & After & Before & After & Thinning & Growth & \\
\hline $0-A$ & 4 & 15 & 1000 & 900 & 3.9775 & 96.9507 & - & 92.9732 & NG \\
\hline$A-B$ & 15 & 16.3 & 900 & 450 & 96.9507 & 57.9752 & 38.9755 & - & $\mathrm{T}$ \\
\hline$B-C$ & 16.3 & 23.4 & 450 & 450 & 57.9752 & 147.1261 & - & 89.1509 & NG \\
\hline$C-D$ & 23.4 & 24 & 450 & 250 & 147.1261 & 84.6848 & 62.4413 & - & $\mathrm{T}$ \\
\hline D-E & 24 & 33.8 & 250 & 250 & 84.6848 & 199.9144 & - & 115.2296 & NG \\
\hline$E-F$ & 33.8 & 34.2 & 250 & 200 & 199.9144 & 166.7851 & 33.1293 & - & $\mathrm{T}$ \\
\hline F-G & 34.2 & 35.7 & 200 & 0 & 166.7851 & 186.2827 & 186.2827 & 19.4976 & FC \\
\hline
\end{tabular}

in which: $\mathrm{dg}=$ quadratic mean diameter $(\mathrm{cm}) ; \mathrm{N}=$ number of plants $/ \mathrm{ha} ; \mathrm{V}=$ stand volume$\left(\mathrm{m}^{3} / \mathrm{ha}\right) ; \mathrm{hdom}=\mathrm{dominant}$ height (m); NG = Natural growth; T = Thinning; FC = Final Cut.

In the second scenario, in contrast to the first one, there is a lower volumetric production, although both values are close, with $192 \mathrm{~m}^{3} \cdot \mathrm{ha}^{-1}$ and $186 \mathrm{~m}^{3} \cdot \mathrm{ha}^{-1}$ for the first and second scenarios, respectively. Also, in the second scenario, there is a lower number of trees at the moment of the final cut, therefore the logs from this management system present a higher aggregated value due to their larger size.

The differences in the time of intervention between the first and second scenarios involves mainly the dg at the moment of the final cut and the management range. Therefore, a global economic analysis of the DMD should be conducted for the best decision-making.

A case study was conducted to evaluate the current management practices adopted in the area for thinning guidelines. Currently these plantings are managed for the production of logs for sawmills and the RDIs used varied between $20 \%$ and $35 \%$. When a random sample unit is added (Figure 6) it reveals that, specifically in this area, the thinnings were performed too early. Only one of the measurements was within the expected interval but it still has not reached the established higher limit of 35\%.

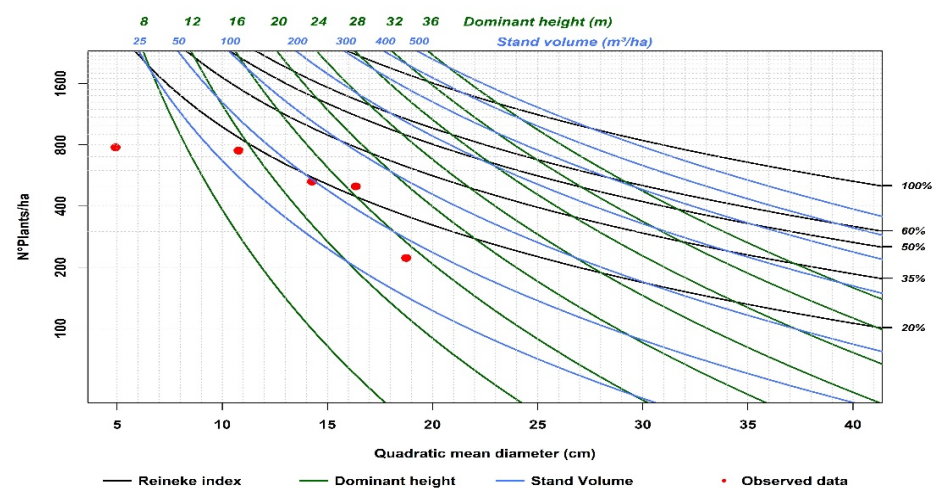

Figure 6 - Simulation for one sample plot. 
At the moment of the first thinning, the sample unit had a diameter of $11 \mathrm{~cm}$, which contradicts the DMD for the studied area, which recommends thinnings when the population presents a diameter of $16 \mathrm{~cm}$.

Besides a diameter lower than the one suggested by the DMD, the thinning intensity was also higher than the one recommended by the DMD, with an initial density close to 800 trees per hectare. Keeping the thinning intensity close to $35 \%$, the remaining population after the first thinning should consist of 520 trees, a value close to the number of trees after the first thinning, although carried out too early.

In the second thinning, with the removal of $55 \%$ of the individuals, the remaining population should have a diameter of $21.5 \mathrm{~cm}$ and not close to $16.5 \mathrm{~cm}$, as observed.

Table 3 presents a summary of the " $\mathrm{dg}$ " and " $\mathrm{N}^{\circ}$ of Plants" variables per hectare, according to the methodology currently used in this study area, as well as the one recommended by the DMD.

Table 3 - Comparison between the thinning results currently adopted by the company and the suggested for Density Managament Diagram (DMD) method.

\begin{tabular}{lcc}
\hline & No Plants / ha & dg (cm) \\
\hline \multirow{3}{*}{ Company } & 800 & 11 \\
& 500 & 16.5 \\
& 220 & - \\
\multirow{2}{*}{ DMD } & 800 & 16.0 \\
& 500 & 21.5 \\
\hline
\end{tabular}

in which: DMD = Density Management Diagram; dg = quadratic mean diameter (cm).

Similar results were found by Medeiros et al. (2018) about the technical age of the first thinning in teak trees because, according to the authors, the thinning age varied between 6 and 8 years, depending on the spacing used, and the current investigation shows that this procedure is being performed too early and with a different intensity from the one proposed by the DMD (Figure 6 and Table 3).

\section{CONCLUSION}

The models proposed by Dean \& Baldwin (1993) were efficient for the development of the Density Management Diagram for teak trees in Mato Grosso.

The Density Management Diagram proved to be an efficient tool highly indicated to simulate thinning scenarios in clonal teak stands.

The simulation yielded in this study points out that in the study area the currently proposed thinnings are being prematurely performed.

\section{REFERENCES}

Alvares, C. A., Stape, J. L., Sentelhas, P. C., Gonçalves, J. L. M., \& Sparovek, G. (2013). Köppen's climate classification map for Brazil. Meteorologische Zeitschrift, 22(6), 711-728. http://dx.doi.org/10.1127/0941-2948/2013/0507.

Arias, L. A. U. (2013). Teak: new trends in silviculture, commercialization and wood utilization (1st ed.). InFoA.

Castedo-Dorado, F., Crecente-Campo, F., Álvarez-Álvarez, P., \& Barrio-Anta, M. (2009). Development of a stand density management diagram for radiata pine stands including assessment of stand stability. Forestry, 82(1), 1-16. http://dx.doi.org/10.1093/forestry/cpm032. 
Dean, T., \& Baldwin, V. C. J. (1993). Using a density: management diagram to develop thinning schedules for loblolly pine plantations (Research Paper, No. SO-275, pp. 12). New Orleans: United States Department of Agriculture.

Kumar, B. M., Long, J. N., \& Kumar, P. (1995). A density management diagram for teak plantations of Kerala in peninsular india. Forest Ecology and Management, 74(1-3), 125-131. http://dx.doi.org/10.1016/0378-1127(94)03499-M.

Long, J. N. (1985). A practical approach to density management. Forestry Chronicle, 61(1), 23-27. http://dx.doi.org/10.5558/tfc61023-1.

Mato Grosso. Secretaria de Planejamento e Coordenação Geral - SEPLAN. (2011). Mato Grosso: clima, análise e representação cartográfica. Cuiabá: Entrelinhas.

Medeiros, R. A., Paiva, H. N., Leite, H. G., Salles, T. T., Araújo Júnior, C. A., \& Dávila, F. S. (2018). Idade técnica do primeiro desbaste de povoamentos de teca em diferentes espaçamentos. IPEF, 45(116), $1-13$.

Minoche, D., Risio-Allione, L., Herrero De Aza, C., \& Martínez-Zurimendi, P. (2017). Density management diagram for teak plantations in Tabasco, Mexico. Biogeosciences and Forestry, 10(6), 909-915. http://dx.doi.org/10.3832/ifor2247-010.

Newton, P. F., \& Weetman, G. F. (1994). Stand density management diagrams for managed black spruce stands. Forestry Chronicle, 70(1), 65-74. http://dx.doi.org/10.5558/tfc70065-1.

Pandey, D., \& Brown, C. (2000). La teca: uma visión global. Unasylva, 51(201), 3-13.

R Core Team. (2017a). R: a language and environment for statistical computing. Vienna: R Foundation for Statistical Computing. Retrieved in 2019, February 26, from https://www.R-project.org/

R Core Team. (2017b). bbmle: tools for general maximum likelihood estimation. R package version 1.0.20. Vienna: R Foundation for Statistical Computing. Retrieved in 2019, February 26, from https://CRAN.R-project.org/package=bbmle

Reineke, L. H. (1933). Perfecting a stand-density index for even-aged forests. Journal of Agricultural Research, 46(7), 627-638.

Retslaff, F. A. S., Figueiredo Filho, A., Machado, S. A., Arce, J. E., \& Jaskiu, E. (2016). Diagrama de manejo da densidade para Pinus taeda no estado do Paraná. Floresta, 46(2), 185-195. http://dx.doi.org/10.5380/rf.v46i2.38301.

Sarkar, D. (2008). Lattice: multivariate data visualization with R. New York: Springer. http://dx.doi.org/10.1007/978-0-387-75969-2.

Schumacher, F. X., \& Hall, F. S. (1933). Logarithmic expression of timber-tree volume. Journal of Agricultural Research, 47(9), 719-734.

Valbuena, P., Del Peso, C., \& Bravo, F. (2008). Stand density management diagrams for two mediterranean pine species in eastern Spain. Investigación Agraria: Sistemas y Recursos Forestales, 17(2), 97-104. http://dx.doi.org/10.5424/srf/2008172-01026.

Wickham, H., François, R., Henry, L., \& Müller, K. (2018). dplyr: a grammar of data manipulation. R package version 0.7.8. Vienna: R Foundation for Statistical Computing. Retrieved in 2019, February 26, from https://CRAN.R-project.org/package=dplyr.

Authors' contributions: JPSM: Conceptualization, Formal Analysis, Methodology, Software, Visualization, Writing original draft, Writing - review \& editing; NC: Methodology, Supervision, Visualization, Visualization, Writing original draft; RM: Methodology, Supervision; MPLCC: Writing - review \& editing; SPCC: Formal Analysis, Methodology, Project administration, Resources, Software, Supervision, Visualization, Writing - original draft, Writing - review \& editing. 